\title{
Environmental Sustainability Scale for Children 60-72 Months Old: A Validity and Reliability Study
}

\author{
Banu Özkan ${ }^{1}$, Mehmet Nur Tuğluk², Nihal Yiğitalp ${ }^{3}$ \\ ${ }^{1}$ Dr.Öğr.Üyesi, Kütahya Dumlupınar Üniversitesi,Eğitim Fakültesi,Okul Öncesi Eğitimi ABD, Turkey \\ ${ }^{2}$ Dr.Öğr.Üyesi,Yıldız Teknik Üniversitesi, Eğitim Fakültesi,Okul Öncesi Eğitimi ABD, Turkey \\ ${ }^{3}$ Öğr.Gör, Yalova Üniversitesi,Meslek Yüksekokulu, Çocuk Gelişimi Pr., Turkey \\ Correspondence: Banu Özkan, Dr.Öğr.Üyesi, Kütahya Dumlupınar Üniversitesi,Eğitim Fakültesi,Okul Öncesi Eğitimi \\ $\mathrm{ABD}$, Turkey.
}

Received: August 27, 2019

Accepted: December 92019

Online Published: December 11, 2019

doi:10.11114/jets.v8i1.4485

URL: https://doi.org/10.11114/jets.v8i1.4485

\begin{abstract}
In recent years, the importance of sustainability has been realized with ever-increasing environmental issues. The preschool period is the most appropriate time for developing an awareness of sustainability as children acquire basic habits during this period and maintain these habits throughout their lives. This study was aimed at developing a scale to evaluate environmental sustainability behaviors in children aged 60-72 months. The validity and reliability study of the scale was limited to 60-72-month-old preschool children, the 2017-2018 academic year and Istanbul (Kadıkoy and Besiktas districts), Kutahya and Yalova provinces. The total number of participants was 426 . The 41 scale items developed by the researchers were submitted to six field specialists for review, and the scale was finalized in accordance with the Lawshe method prior to commencing validity and reliability studies. The study data were gathered with the Environmental Sustainability Scale for Children aged 60-72 Months that comprised 2 factors and 20 items. The factor structure of the scale was determined after a theoretical literature review and peer-debriefing. First and second order confirmatory factor analyses were performed for the construct finalized after peer-debriefing. In the reliability study, internal consistency was examined, and the Cronbach's alpha was computed as .92. In conclusion, the study results indicated that the scale was a valid and reliable evaluation instrument.
\end{abstract}

Keywords: sustainability, preschool education, children, 60-72 months

\section{Introduction}

Recently, sustainability has become one of the most discussed topics with the continuous increase in environmental issues. Coined in the 1970s, the term sustainability was characterized as "meeting the needs of the present without compromising the ability of future generations to meet their own needs," in Our Common Future, a Report published by the World Commission on Environment and Development (WCED) in 1987 under the sponsorship of the United Nations (Önder and Özkan, 2013). Therefore, sustainability is critical to addressing current and future problems, as well as, shaping the present and the future. Although sustainability is everyone's duty, educators have a much greater responsibility (Davis, 2010).

Educators have a significant role in promoting necessary awareness, attitude, knowledge, skill and participation. The acquisition of these attributes in early childhood potentially plays an influential role in shaping the future for solving the issue of sustainability, albeit in the long term. Growing up in a world that maximizes life opportunities allows children to improve their capacity as active citizens and contribute to hope, peace, equality and sustainability (Davis, 2008). It is critical to adopt a sustainable development approach in future educational efforts and integrate sociocultural, environmental and economic sustainability into the curriculum (Toran, 2016).

Environmental sustainability involves passing on ecological environmental resources by improving or preserving their present state. In general, it addresses issues such as poverty, migration, food and water shortage and health problems in poor countries due to the depletion of natural resources, increasing greenhouse gas emissions, flooding of fertile lands, rising sea level and polluted waterways (Siraj-Blatchford, Smith \& Samuelsson, 2010).

A mediator is required for sustainable development to succeed. Education is regarded as an important tool for 
sustainability (UNESCO, 1997) and the education of both individuals and communities has a critical role in achieving a sustainable world.

Sustainability education in early years provides the basis for the formation of desirable attention and attitudes in early childhood (Güler Yıldız and Korkmaz, 2017). Sustainability education in early childhood is generally provided in line with the goals of environmental education (Haktanır, Güler, Yılmaz and Kurtulmuş, 2010; Kahriman-Öztürk, Olgan and Güler, 2012). The goals of environmental education are categorized in five groups: awareness, knowledge, attitude, skill and participation (Güler Yıldı, 2017). Awareness concerns the consciousness and sensitivity of individuals and communities about the environment in general and environmental issues. Knowledge is attained through the acquisition of a fundamental perception regarding the environment and environmental issues, as well as, the position and the responsibility of humanity. Attitude is achieved through understanding the essence of social values and building motivation for active participation in efforts to protect and ameliorate the environment. Skill signifies developing the ability of individuals and communities to solve environmental issues. Finally, participation facilitates the realization of one's responsibilities, and is conducive to developing environmental responsibility, as well as, a sense of exigency to take the necessary measures when faced with an environmental issue (Güler Yıldız, 2017; UNESCO, 1977).

According to Ayvaz et al. (1999), environmental education is of critical importance in preschool education programs due to three reasons:

1. Environmental education is important for the self.

2. Human activity gradually impacts the Earth, and there is a need for young generations to develop solutions to ecological problems.

3. Nature, as a model, constitutes a core field in preschool education programs.

According to Davis (2010), sustainability education is positive, promising, affirmative, future-oriented, change-driven, learner-centered, community-oriented, lifelong, long-term, interdisciplinary and translational. Furthermore, environmental education must be multidimensional, and training programs must be integrated into the curriculum by considering all aspects for sustainability (Güler, 2007; Kahriman and Güler Yıldız, 2017).

\section{The Objective and Significance of the Study}

The study was aimed at developing a scale to evaluate environmental sustainability behaviors in children aged 60-72 months. In line with this goal, a review of literature on sustainability and early childhood was conducted for the development of the scale.

The literature review mostly yielded studies that focused on environmental education, one of the basic dimensions of sustainability education (Güler, 2009; Özdemir, 2007; Şengül,2001). The majority of these studies were conducted to examine student attitude at primary school level (Alp, Ertepınar, Tekkaya and Yılmaz, 2006; Tuncer, Ertepınar, Tekkaya and Sungur, 2005; Y1lmaz, Boone and Anderson, 2004). There were also numerous studies that investigated university student attitudes towards the environment or environmental literacy in tertiary education (Berberoğlu and Tosunoğlu, 1995; Özsoy, Özsoy and and Kuruyer, 2011; Teksöz, Şahin and Ertepınar, 2010). Research focusing on the preschool period mainly comprised qualitative studies that attempted to identify and assess opinions, as well as, the current situation (Güler, 2009; Güler-Yıldız, Özdemir-Şimşek, Eren and Aydos, 2017; Kahriman Öztürk, Olgan and Güler Y1ldız, 2012; Kahriman, Olgan and Tuncer, 2012). Particularly studies on the integration of sustainability education into the preschool curriculum establish the importance of including this concept in preschool education programs (Kahriman-Öztürk, Olgan and Güler, 2012; McNichol, Davis and O'Brien, 2011). In addition, one study related a practical example of sustainability education in the preschool period (Davis, 2005).

Investigation of the objectives and contents of the master's theses that directly emphasized education for sustainability showed that the majority were conducted in the field of science education (Çolak, 2012; Demirci, 2014; İnel, 2009; Keleş, 2007; Sağdıç, 2013; Şahin, 2008; Tamkan, 2008; Türer, 2010), in which the participants were mostly teachers or other professionals attending in-service training (Aydoğan, 2010; Çolak, 2012; Engin, 2010; Gezer, 2010; Kahriman, 2016; Korkmaz, 2014; Özlü, 2011; Sağdıç, 2013; Tamkan, 2008) or prospective teachers (Demirci, 2014; Keleş, 2007; Şahin, 2008; Türer, 2010). In addition, most of these studies were aimed at investigating opinion, awareness, belief and attitude (Akpınar, 2011; Aydoğan, 2010; Çolak, 2012; Demirci, 2014; Engin, 2010; Kahriman, 2010; Kahriman, 2016; Keleş, 2007; Korkmaz, 2014; Sağdıç, 2013; Şahin, 2008; Tamkan, 2008; Türer, 2010). On the other hand, very few studies attempted to conduct practical research (Gezer, 2010) or to assess the effects of a particular practice (Cengizoğlu, 2013; Özlü, 2011).

Past research on sustainability in the field of early childhood education is quite limited. These studies are listed in detail below: 
In her doctoral thesis entitled "Comparison of Early Childhood Education Educators' Education for Sustainable Development Practices Across Eco versus Ordinary Preschools," Kahriman (2016) investigated the opinions and practices of early childhood teachers working at eco and non-eco preschools on sustainable development education. Furthermore, she identified and compared the variables that predicted sustainable development education (SDE) practices of teachers working at eco-certified and ordinary preschools. She administered a series of scales and tests to preschool teachers employed at 111 preschools in Istanbul, Ankara, Antalya and Eskişehir. The study data were analyzed with hierarchical linear modeling (HLM), a descriptive and multilevel method of analysis. In HLM analysis, a higher score for attitude towards SD indicated greater SDE practice. In addition, SDE practices of the teachers working at eco-certified preschools were predicted through membership in an environmental or sustainable development NGO. Among the teachers employed at non-eco preschools, those with prior SDE experience scored higher in current practices.

Cengizoğlu (2013) investigated the influence of the preschool education program for sustainable development on the perception of preschoolers regarding the relationship between human beings and the environment in view of deforestation, biological diversity and climate change. The thesis entitled "Education for Sustainability: Exploring Changes on Young Children's Perception toward Environmental Problems" was conducted with 60-66-month-old preschool children $(\mathrm{N}=18)$ attending an eco-school in Ankara as a qualitative case study. The study data comprised children's drawings themed "environment and humans" and semi-structured interviews with children, before and after administration. The program consisting of 14 activities (drama, art, games, science, language, etc.) was completed in four weeks. The results revealed a change of perception in the participating preschoolers as to the relationship between human beings and the environment in view of deforestation, biological diversity and climate change. The children attending the education program for sustainable development were also found to have developed an understanding of the interaction between deforestation, biological diversity and climate change. Furthermore, the children participating in the program acquired the ability of critical thinking and proposed their own solutions for a sustainable future.

In her master's thesis entitled "Evaluation of preschool educational institutions using eco-school program for education for sustainable development," Korkmaz (2014) examined educational practices for sustainable development in three subscales (i.e. environmental, socio-cultural and economical) and environmental aspects of public and private preschools with eco-school status. Study group schools were selected with criterion sampling. The study group comprised 4 public and 4 private eco-preschools with green flag status located at Çankaya and Yenimahalle districts of Ankara. The mixed method study utilized both qualitative and quantitative data collection instruments. In addition to the observations recorded via the School Observation Form, individual interviews were carried out with 8 school principals and 16 preschool teachers to determine the common aspects of the study group schools. In addition, the Teacher Scale for ESD Practices was administered to 40 preschool teachers. Evaluation of the environmental aspects of public and private preschools showed that private preschools had higher frequency values than public schools in environmental, socio-cultural and economic sub-scales. The majority of the public and private school principals were found to have high levels of ESD awareness. Private preschool teachers scored higher in awareness than public preschool teachers. In addition, private preschool teachers had significantly higher mean scores in the environmental and economic subscales, as well as, in the overall scale.

In her study on how to include sustainability in early childhood education, Davis (2008) highlighted the fact that children would be the ones to bear the negative consequences of sustainability-related issues, and embedded sustainability practices into education programs in Australian early childhood centers to provide children with sustainability education experiences. Within the scope of the study, 2.5-5-year-old children were engaged in various activities under the Sustainable Planet Project. One of the most remarkable findings of the study is the descriptive analyses based on the water conservation project. A mini-project concerning excessive use of water facilitated children's realization that their friends poured more water into their cups than they could drink and dumped the remaining water. The project, which encompassed numerous activities with the interactive participation of the school, the parents and the students, received positive feedback that the children had started to reflect the awareness built up during the project to the environment.

The great majority of these studies focused on cases by ad-hoc inferences. The need for an evaluation instrument that allows the generalization of environmental sustainability behaviors in early childhood demonstrates the significance of the present study.

\section{Methods}

\section{Study Group}

The validity and reliability study of the scale was limited to 60-72-month-old preschoolers, the 2017-2018 academic year and Istanbul (Kadıkoy and Besiktas districts), Kutahya and Yalova provinces. The total number of participants was 426. 


\section{The Development of the Data Collection Instrument}

The 41 scale items developed by the researchers in the item development stage were submitted to six field specialists for review, and the scale was finalized in accordance with the Lawshe method prior to commencing validity and reliability studies. The study data were gathered with the Environmental Sustainability Scale for Children aged 60-72 Months which comprised 2 factors and 20 items.

\section{Data Collection}

The scale was administered to 426 children aged 60-72 months who attended preschool in Istanbul (Kadikoy and Besiktas districts), Kutahya and Yalova provinces in the 2017-2018 academic year. The five-point Likert-type scale (Strongly Disagree, Disagree, Partially Agree, Agree, Strongly Agree) was completed by the teacher for each child.

\section{Data Analysis}

The factor structure of the scale was determined after a theoretical literature review and peer-debriefing. Possible theoretical dimensions were examined with an exploratory factor analysis. The scale comprised two subscales, namely awareness and consciousness. First and second order confirmatory factor analyses were performed for the construct finalized after peer-debriefing. A confirmatory factor analysis aims to test whether a factorial model consisting of numerous observable variables (latent variables) is consistent with actual data. The model can characterize a structure constructed with data from an empirical study or based on a particular theory (Sümer, 2000). In CFA, many fit indices are used to evaluate the validity of the model, the most common of which are Chi-Square Goodness of Fit $(\chi 2)$, Root Mean Square Error of Approximation (RMSEA), Comparative Fit Index (CFI), Non-Normed Fit Index (NNFI), Normed Fit Index (NFI) and Goodness of Fit Index (GFI) (Cole, 1987; Sümer, 2000). X2/d $<3$; $0<$ RMSEA $<0.05 ; 0.97 \leq N N F I \leq 1$; $0.97 \leq \mathrm{CFI} \leq 1 ; 0.95 \leq \mathrm{GFI} \leq 1$ and $0.95 \leq \mathrm{NFI} \leq 1$ ranges indicate a perfect fit for the values observed in the scale model, while $4<\mathrm{X} 2 / \mathrm{d}<5 ; 0,05<\mathrm{RMSEA}<0.08 ; 0.95 \leq \mathrm{NNFI} \leq 0.97 ; 0.95 \leq \mathrm{CFI} \leq 0.97 ; 0.90 \leq \mathrm{GFI} \leq 0.95$ and $0.90 \leq \mathrm{NFI} \leq 0.95$ indicate an acceptable fit (Kline, 2005; Sümer, 2000). In addition, the Cronbach's alpha internal consistency coefficient was computed to investigate scale reliability.

Items that loaded on more than one factor and those with low item-total correlation were identified and removed, which left a total of 20 items in the scale. An exploratory factor analysis was performed once more with the remaining items. Initial analysis yielded suitable KMO and Bartlett's test results. A two-factor structure with an eigenvalue greater than 1 was extruded. The two factors explained $63.90 \%$ of the total variance.

\section{Validity Study}

First and second order confirmatory factor analyses were conducted to test the validity of the scale.

\section{The Factor Structure of the Scale}

At this stage, CFA was performed to test whether the 20-item and two-subscale structure of the scale was confirmed, and all the items were retained in the scale. The path diagram is given in Figure 1.

Fit indices were computed as $\chi^{2}=611.82, \mathrm{X}^{2} / \mathrm{sd}=3.62$, RMSEA $=0.077, \mathrm{CFI}=0.91$, IFI=0.91, NNFI=0,92 and NFI=0,90. Examination of the coefficients that represent the relationship between the observable variables and the factors of the factor structure model showed that all the coefficients were at an acceptable level. Fit statistics calculated with CFA indicated that the designated structure of the construct possessed a high degree of fitness with the empirical data. 


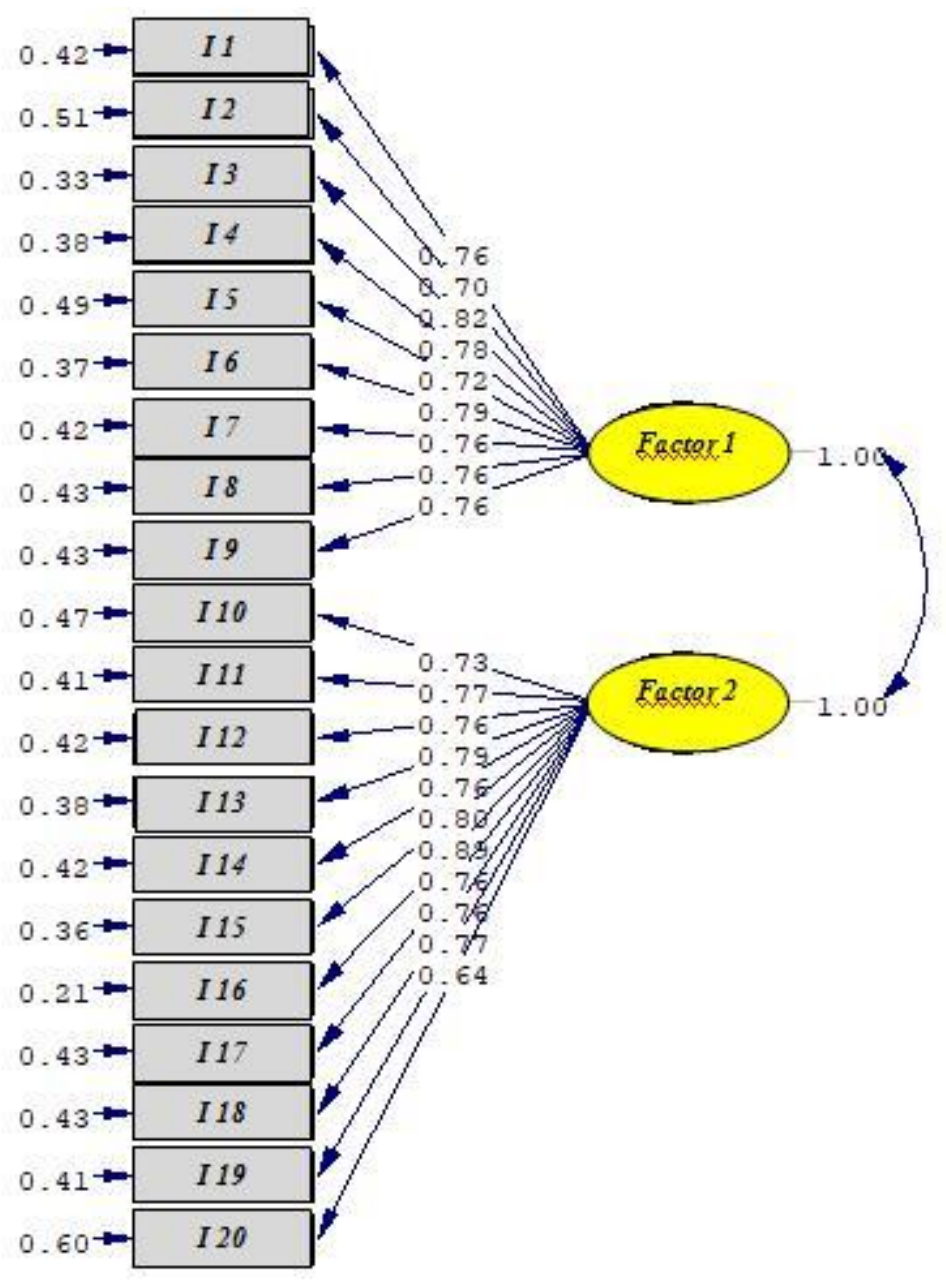

Figure 1. Path Diagram for the scale

Regression and $\mathrm{t}$ values for the items are presented in Table 1.

Table 1. Regression and $t$ values for the scale

\begin{tabular}{llllll}
\hline Items & $\begin{array}{l}\text { Regression } \\
\text { values }\end{array}$ & t values & Items & $\begin{array}{l}\text { Regression } \\
\text { values }\end{array}$ & t values \\
\hline I1 & 0.76 & 15.10 & I11 & 0.77 & 15.38 \\
I2 & 0.70 & 13.38 & I12 & 0.76 & 15.10 \\
I3 & 0.82 & 16.75 & I13 & 0.79 & 15.90 \\
I4 & 0.78 & 15.74 & I14 & 0.76 & 15.20 \\
I5 & 0.72 & 13.80 & I15 & 0.80 & 16.35 \\
I6 & 0.79 & 16.03 & I16 & 0.89 & 19.26 \\
I7 & 0.76 & 15.07 & I17 & 0.76 & 15.05 \\
I8 & 0.76 & 14.91 & I18 & 0.76 & 15.00 \\
I9 & 0.76 & 14.97 & I19 & 0.77 & 15.38 \\
I10 & 0.73 & 14.21 & I20 & 0.64 & 11.91 \\
\hline
\end{tabular}

Table 1 showed that the regression coefficients and the $t$ values were significant $(t>1.92)$, and that the model was confirmed. 


\section{Reliability Study}

The Cronbach's alpha, a coefficient of internal consistency, was calculated to investigate scale reliability. Tezbasaran (1997:47) explains that an acceptable reliability coefficient in a Likert-type scale must be as close to 1 as possible. The results indicated that the evaluation instrument employed in the study had a high level of reliability.

\section{Results}

Table 2. Content validity results

\begin{tabular}{ll}
\hline Number of Specialists & Minimum Value \\
\hline 5 & 0.99 \\
6 & 0.99 \\
7 & 0.99 \\
8 & 0.78 \\
9 & 0.75 \\
10 & 0.62 \\
11 & 0.59 \\
12 & 0.56 \\
\hline
\end{tabular}

The table shows that the minimum content validity ratio (CVR) should be 0.99 if the scale is submitted to six specialists for review. Statistical analysis of the specialist ratings yielded a CVR of 1.00, and none of the scale items were removed when they were assessed in accordance with this CVR. According to the formula used in the Lawshe method, CVR is calculated by subtracting 1 from the ratio of the number of specialists who opined to keep the item in the scale to the total number of specialists. If the CVR value is equal to or smaller than 0 , the item must be eliminated. Then, the significance of the items with positive CVR values is tested. For ease of calculation, Veneziano and Hooper (1997) tabulated minimum CVR values at $\mathrm{P}<0.05$ level of significance. The minimum values for the number of specialists express the statistical significance of the item. The items with values greater than the minimum value are included in the scale, while those with values smaller than the minimum value are eliminated (Lawshe, 1975; Veneziano and Hooper, 1997 as cited in Yurdugül, 2005).

Table 3. KMO and Bartlett's test results after exploratory factor analysis of the 20 items

\begin{tabular}{lll}
\hline KMO and Bartlett's Test & & \\
\hline KMO & & .899 \\
Bartlett's Test of Sphericity & Approx. Chi-Square & 4658.406 \\
& Df & 190 \\
& P & 0.000
\end{tabular}

Initial analysis revealed acceptable KMO and Bartlett's test results. The KMO value was computed as .89 . 
Table 4. Factor loadings

\begin{tabular}{|c|c|c|}
\hline \multicolumn{3}{|c|}{ Rotated Component Matrix } \\
\hline & \multicolumn{2}{|c|}{ Component } \\
\hline & 1 & 2 \\
\hline $\mathrm{I} 22$ & .843 & \\
\hline $\mathrm{I} 15$ & .833 & \\
\hline $\mathrm{I} 14$ & .812 & \\
\hline $\mathrm{I} 16$ & .793 & \\
\hline $\mathrm{I} 21$ & .787 & \\
\hline I29 & .784 & \\
\hline $\mathrm{I} 23$ & .746 & \\
\hline $\mathrm{I} 10$ & .743 & \\
\hline I41 & .728 & \\
\hline $\mathrm{I} 20$ & .725 & \\
\hline $\mathrm{I} 25$ & .724 & \\
\hline I7 & & .845 \\
\hline $\mathrm{I} 2$ & & .821 \\
\hline I8 & & .786 \\
\hline $\mathrm{I} 38$ & & .781 \\
\hline I39 & & .778 \\
\hline $\mathrm{I} 3$ & & .757 \\
\hline $\mathrm{I} 13$ & & .752 \\
\hline I9 & & .733 \\
\hline $\mathrm{I} 31$ & & .716 \\
\hline
\end{tabular}

CFA was conducted to test whether the 20-item and two-subscale structure of the scale was confirmed. Items with a statistically non-significant $t$ value were investigated in the first order CFA, which did not yield any items with a statistically non-significant t value. However, a second order CFA could not be performed as the error variance of the second factor was too high (>0.95). All the items were retained in the two-subscale evaluation instrument.

Examination of the coefficients that represent the relationship between the observable variables and the factors of the factor structure model indicated that all the coefficients were at an acceptable level. The first and the second subscales were entitled awareness and consciousness, respectively.

Table 5. Reliability results

\begin{tabular}{ll}
\hline Reliability Statistics & \\
\hline Cronbach's Alpha & N of Items \\
.926 & 20
\end{tabular}

The Cronbach's alpha internal consistency coefficient was computed to investigate scale reliability. The Cronbach's alpha values for the awareness subscale, the consciousness subscale and the overall scale were found to be .92 , .94 and .92 , respectively.

\section{Conclusion, Discussion and Recommendations}

The results showed that the scale developed for the study was a valid and reliable evaluation instrument for investigating sustainable environmental behaviors in children aged 60-72 months. Although the literature contains studies on sustainable environmental behaviors carried out with children in early childhood, very few of these studies 
focus on scale development. In the validity and reliability study for the "Environmental Awareness Assessment Scale for 48-66-Month Children," Gökçeli and Kandır (2016) obtained statistically adequate results and concluded that the scale was valid and reliable. In their study, Kesicioğlu and Alisinanoğlu (2009) found that environmental attitude in children aged 60-72 months did not vary by place of residence, mother's educational level, father's educational level, monthly household income, mother's occupation and father's occupation, but displayed a significant difference with respect to gender. The results of the study by Haktanır and Çubuk (2000) investigating environmental perception among preschoolers revealed that children of university graduate mothers had higher environmental awareness. In her doctoral study, Cevher Kalburan (2009) examined the validity and reliability of the "Children's Environmental Attitudes Scale" and the "New Ecological Paradigm Scale," and found that both instruments were valid and reliable.

In conclusion, the researchers would like to make the following recommendations for future studies:

- As the scale developed in the study is aimed at children aged 60-72 months, new scales for children in different age groups can be developed.

- Curricula and training programs on environmental education, awareness and sustainability can be developed for preschool children to investigate their effects.

- The review of literature yielded only a few evaluation instruments on environmental awareness and sustainability for preschool children. Studies aiming to develop of new relevant scales can be conducted.

\section{References}

Akpınar, P. (2011). Sürdürülebilir kalkınma için eğitim konusunda ilköğretim okulu yöneticilerinin görüşleri. Yayınlanmamış yüksek lisans tezi. Hacettepe Üniversitesi, Ĕ̈itim Bilimleri Enstitüsü, Ankara.

Alp, E., Ertepinar, H., Tekkaya, C., \& Y1lmaz, A. (2006). A study on children's environmental knowledge and attitudes: The effect of grade level and gender. International Research in Geographical and Environmental Education, 15, 210-223. https://doi.org/10.2167/irgee193.0

Aydoğan, A. (2010). Sosyal bilgiler öğretmenlerinin sürdürülebilir kalkınma konusuyla ilgili kazanımların öğretimine ilişkin görüşleri. Yayınlanmamış yüksek lisans tezi. Niğde Üniversitesi, Sosyal Bilimler Enstitüsü, Niğde.

Ayvaz, Z., Öztürk, M., Balcı, A., Uzunoğlu, S., Noyan, Ö. F., Pazarlığlu, M. V., ... Bakaç, M. (1999). Okul öncesi çevre eğitimi. İzmir: Çevre Eğitimi ve Araştırma Vakfi (ÇevKor: Çevre Eğitimi Merkezi Yayınları: 6).

Berberoğlu, G., \& Tosunoğlu, C. (1995). Exploratory and confirmatory factor analyses of an environmental attitude scale (EAS) for Turkish university students. The Journal of Environmental Education, 26, 40-44. https://doi.org/10.1080/00958964.1995.9941444

Cengizoğlu, S. (2013). Education for Sustainability: Exploring Changes on Young Children's Perception toward Environmental Problems. [Sürdürülebilir kalkınma için eğitim programının okul öncesi dönem çocuklarının insançevre ilişkisi algısına etkisinin incelenmesi] Yayınlanmış yüksek lisans tezi, Orta Doğu Teknik Üniversitesi, Ankara.

Cevher-Kalburan, F. N. (2009). Çocuklar için çevresel tutum ölçeği” ile "yeni ekolojik paradigma ölçeği” nin geçerlik güvenirlik çalışması ve çevre eğitim programının etkisinin incelenmesi.Yayımlanmamış Doktora Tezi, Gazi Üniversitesi Ĕ̆itim Bilimleri Enstitüsü, Ankara.

Colak. C. (2012). İlköğretim-lise öğretmen ve öğrencilerinin sürdürülebilir kalkınma ile biyolojik çeşitliliğe ilişkin görüşleri üzerine bir çalışma. Yayınlanmamış yüksek lisans tezi. Karadeniz Teknik Üniversitesi, Eğitim Bilimleri Enstitüsü, Trabzon.

Cole, D. A. (1987). Utility of confirmatory factor analysis in test validation research. Journal of Consulting and Clinical Psychology, 55, 584-594. https://doi.org/10.1037/0022-006X.55.4.584

Davis, J. M. (2005). Educating for sustainability in the early years: Creating cultural change in a child care setting. Australian Journal of Environmental Education, 21, 47-55. https://doi.org/10.1017/S081406260000094X

Davis, J. M. (2008). What might education for sustainability look like in early childhood? Samuelsson, I.P ve Kaga, Y. (Ed.). The contribution of early childhood education to a sustainable society,18-24. Paris: UNESCO.

Davis, J. M. (2010). Young children and the environment: Early education for sustainability. Sydney: Cambridge Press. https://doi.org/10.1017/CBO9780511845390

Demirci, S. (2014). Sürdürülebilirlik çerçevesinde insan nüfus artışı ölçeğinin geliştirilmesi ve geçerliği. Yayınlanmamış yüksek lisans tezi. Orta Doğu Teknik Üniversitesi, Sosyal Bilimler Enstitüsü, Ankara.

Engin, H. (2010). Coğrafya eğitiminde sürdürülebilir kalkınma, sürdürülebilirlik eğitimi ve çevre eğitimi konularının 
kazandırılması. Yayınlanmamış yüksek lisans tezi. Marmara Üniversitesi, Eğitim Bilimleri Enstitüsü, İstanbul.

Gezer, Ş. F. (2010). Sürdürülebilirliğin hizmet-içi eğitimle okul öncesi öğretime entegre edilmesi: Dönüştürücü öğrenmeye yönelik bir çaba. Yayınlanmamış yüksek lisans tezi. Orta Doğu Teknik Üniversitesi, Sosyal Bilimler Enstitüsü, Ankara.

Gokceli, F. K., \& Kandır, A. (2016). 48-66 Aylık Çocuklar için Çevresel Farkındalığı Değerlendirme Ölçeği” nin Geçerlik Güvenirlik Çalışması. H.Ü. Sağllk Bilimleri Fakültesi Dergisi. 3(3), 16-45.

Guler, T. (2007). "Yaygın Eğitimde Çevre”, Çevre Eğitimi, ss. 99-126, Türkiye Çevre Vakfı Yayını, Ankara.

Guler, T. (2009). "Ekoloji Temelli Bir Çevre Eğitiminin Öğretmenlerin Çevre Eğitimine Karşı Görüşlerine Etkileri”, Ë̆itim ve Bilim, 34(151), 30-43.

Guler, Y. T. (2017). “Çevre Ĕgitimi” Okul Öncesi Dönemde Fen Eğitimi, (Ed. B. Akman, G. Balat ve T. Güler Yıldı) Genişletilmiş 5. Baskı, ss. 267-289, Pegem Akademi Yayıncılık, Ankara.

Guler, Y. T., \& Korkmaz, A. (2017). “Erken Çocukluk Eğitiminde Sürdürülebilir Gelişme İ̧̧in Eğitim”. E. Gökçe Türk (Ed.). Çocuk ve Çevresi(s.219-254). Ankara: Ankara Üniversitesi Basımevi.

Guler, Y. T., Özdemir, S. P., Eren, S., \& Aydos, E. H. (2017). An Analysis of the Views and Experiences of Children Who Are 48-66 Months Old, Their Parents, and Teachers about" Sustainable Development". Educational Sciences: Theory and Practice, 17(2), 653-677. https://doi.org/10.12738/estp.2017.2.0013

Haktanır, G., \& Çubuk, B. (2000). Okul Öncesi Dönemdeki Çocukların Çevre Algıları. IV. Fen Bilimleri Eğitimi Kongresi, Bildiriler Kitabı, Hacettepe Üniversitesi Eğitim Fakültesi, Ankara.

Haktanır, G., Güler, T., Yılmaz, A., \& Kurtulmuş, Z. (2010). Perceptions of Turkish early childhood pre-service teachers about sustainable development, XXVI OMEP World Congress, Göteborg, Sweden, 09-13 August 2010.

İnel, D. (2009). Fen ve teknoloji dersinde probleme dayalı öğrenme yöntemi kullanımının öğrencilerin kavramları yapılandırma düzeyleri, akademik başarıları ve sorgulayıcı öğrenme becerileri algıları üzerindeki etkileri. Yayınlanmış Yüksek Lisans Tezi. Dokuz Eylül Üniversitesi Eğitim Bilimleri Enstitüsü, İzmir.

Kahriman, D. (2010). Preschool children's attitudes towards selected environmental issues. Unpublished Master's Thesis. ODTÜ, Ankara.

Kahriman, D. (2016). Comparıson Of Early Chıldhood Education Educators' Education For Sustainable Development Practıces Across Eco Versus Ordınary Preschools. [Eko ve eko olmayan eğitim kurumları arasında erken çocukluk eğitimcilerinin sürdürülebilir kalkınma eğitimi uygulamalarının karşılaştırılması]. Yayınlanmış doktora tezi. Orta Doğu Teknik Üniversitesi, Ankara.

Kahriman, D., \& Güler, Y. T. (2017). “Okul Öncesi Dönemde Sürdürülebilir Gelişme için Eğitim” Okul Öncesi Dönemde Fen Eğitimi, (Ed. B. Akman, G. Balat ve T. Güler Yıldız) Genişletilmiş 5. Baskı, ss. 245-265, Pegem Akademi Yayınc1lık, Ankara.

Kahriman-Öztürk, D., Olgan, R., \& Güler, T. (2012). Preschool children's ideas on sustainable development: how preschool children perceive three pillars of sustainability with the regard to 7R. Educational Sciences Theory \& Practice - Special Issue, 2987-2995.

Kahriman-Öztürk, D., Olgan, R., \& Tuncer, G. (2012). A qualitative study on Turkish preschool children's environmental attitudes through ecocentrism and anthropocentrism. International Journal of Science Education, 34, 629-650. https://doi.org/10.1080/09500693.2011.596228

Keles, Ö. (2007). Sürdürülebilir yaşama yönelik çevre eğitimi aracı olarak ekolojik ayak izinin uygulanması ve değerlendirilmesi. Yayınlanmamış doktora tezi. Gazi Üniversitesi, Eğitim Bilimleri Enstitüsü, Ankara.

Kesicioğlu, O. S., \& Alisinanoğlu, F. (2009). 60-72 Aylık Çocukların Çevreye Karşı Tutumlarının Çeşitli Değişkenler Açısından İncelenmesi. Ahi Evran Üniversitesi Eğitim Fakültesi Dergisi. 10(3), 37-48.

Kline, R. B. (2005). Principles and Practice of Structural Equation Modeling (2nd Edition ed.). New York: The Guilford Press.

Korkmaz, A. (2014). Eko-okul programını uygulayan okul öncesi eğitim kurumlarının sürdürülebilir gelişme için eğitim açısından değerlendirilmesi. Yayınlanmış yüksek lisans tezi. Hacettepe Üniversitesi, Eğitim Bilimleri Enstitüsü, Ankara.

Lawshe, C. H. (1975). A quantitative approach to content validity. Personel Psychology, 28, 563-575. https://doi.org/10.1111/j.1744-6570.1975.tb01393.x 
McNichol, H., Davis, J. M., \& O’Brien, K. R. (2011). An ecological footprint for an early learning center: identifying opportunities for early childhood sustainability education through interdisciplinary research. Environmental Education Research, 17(5), 689-704. https://doi.org/10.1080/13504622.2011.572161

Onder, A., \& Ozkan, B. (2013). Sürdürülebilir çocuk gelişimi: Okul öncesi etkinliklerle çevre eğitimi. Ankara: Anı Yayıncilik.

Ozdemir, O. (2007). Yeni bir çevre eğitimi perspektifi: Sürdürülebilir gelişme amaçlı eğitim. Eğitim ve Bilim, 32(145), 23-39.

Ozlü, Ö. (2011). Uzaktan eğitim metoduyla sürdürülebilirlik eğitimi uygulamaları üzerine bir araştırma. Yayınlanmamış yüksek lisans tezi. Maltepe Üniversitesi, Sosyal Bilimler Enstitüsü, İstanbul.

Ozsoy, S., Ozsoy, G., \& Kuruyer, H. G. (2011). Turkish pre-service primary school teachers' environmental attitudes: Effects of gender and grade level. Asia-Pacific Forum on Science Learning and Teaching, 12(2).

Sagdıç, A. (2013). Türkiye'deki ilköğretim öğretmenlerine sürdürülebilir kalkınma eğitimi konusunda yakından bakış. Yayınlanmamış yüksek lisans tezi. Orta Doğu Teknik Üniversitesi, Sosyal Bilimler Enstitüsü, Ankara.

Şahin, E. (2008). Sürdürülebilirliğe yönelik yeşil bir müfredat uygulaması için göstergelerin incelenmesi. Yayınlanmamış doktora tezi. Orta Doğu Teknik Üniversitesi, Fen Bilimleri Enstitüsü, Ankara.

Şengül, M. (2001). Bir çevre yönetimi aracı olarak çevre için eğitim. Amma İdaresi Dergisi, 34(4), 137-155.

Siraj-Blatchford, J., Smith, K., \& Samuelsson, I., P. (2010). Education for sustainable development in the early years. Mondiale: OMEP.

Sümer, N. (2000). Yapısal eşitlik modelleri: Temel kavramlar ve örnek uygulamalar. Türk Psikoloji Yazıları, 3(6), 49-74.

Tamkan, R. (2008). Türkiye'nin doğal zenginliklerinin sürdürülebilirliği ve ortaöğretim biyoloji öğretmenlerinde farkındalık. Yayınlanmamış yüksek lisans tezi. Marmara Üniversitesi, Eğitim Bilimleri Enstitüsü, İstanbul.

Teksöz, G., Şahin, E., \& Ertepınar, H. (2010). Çevre okuryazarlı̆̆ı, öğretmen adayları ve sürdürülebilir bir gelecek. Hacettepe Üniversitesi Ĕ̈itim Fakültesi Dergisi, 39, 307-320.

Tezbasaran, A. (1997). Likert Tipi Ölçek Geliştirme Kılavuzu. (İkinci baskı), Türk Psikologlar Derneği Yayını, Ankara.

Toran, M. (2016). Sürdürülebilir Anaokulları: Okul Öncesi Eğitim Kurumlarının Değerlendirilmesi. Abant İzzet Baysal Üniversitesi Ĕ̈itim Fakültesi Dergisi, 16(3), 1035-1046.

Tuncer, G., Ertepinar, H., Tekkaya, C., \& Sungur, S. (2005). Environmental attitudes of young people in Turkey: Effects of school type and gender. Environmental Education Research, 11, 215-233. https://doi.org/10.1080/1350462042000338379

Turer, B. (2010). Fen bilgisi ve sosyal bilgiler öğretmen adaylarının sürdürülebilir kalkınma farkındalıklarının belirlenmesi. Yayınlanmamış yüksek lisans tezi. Ondokuz Mayıs Üniversitesi, Eğitim Bilimleri Enstitüsü, Samsun

UNESCO (1997). Educating for a sustainable future [Çevrim-içi: http://unesdoc.unesco.org/images/0011/001106/110686eo.pdf], Erişim Tarihi: 25 Haziran 2018.

Veneziano L., \& Hooper J. (1997). A method for quantifying content validity of health-related questionnaires. American Journal of Health Behavior, 21(1), 67-70.

WCED. (1987). Report of the world commission on environment and development, [Çevrim-içi: http://www.un-documents.net/wced-ocf.htm] Erişim Tarihi: 25 Haziran 2018.

Yllmaz, O., Boone, W. J., \& Anderson, H. O. (2004). Views of elementary and middle school Turkish students toward environmental issues. International Journal of Science Education, 26, 1527-1546. https://doi.org/10.1080/0950069042000177280

Yurdugül, H. (2005). Ölçek geliştirme çalışmalarında kapsam geçerliği için kapsam geçerlik indekslerinin kullanılması. XIV. Ulusal Eğitim Bilimleri Kongresi, 28-30 Eylül 2005. Denizli: Pamukkale Üniversitesi.

\section{Copyrights}

Copyright for this article is retained by the author(s), with first publication rights granted to the journal.

This is an open-access article distributed under the terms and conditions of the Creative Commons Attribution license which permits unrestricted use, distribution, and reproduction in any medium, provided the original work is properly cited. 